\title{
The Security Council and the Repression of Maritime Piracy: The Case of Somalia
}

\section{Safwan Maqsood}

Maritime piracy in the Somali territorial waters has been the focus of attention of international society for at least twelve years, and indeed the crime of piracy threatens international peace and security in a region through which half of the world's crude oil passes. In the three-decade absence of a Somali State, intervention by the Security Council is required to suppress such crimes and ensure freedom of maritime navigation. The Council resolutions based on Chapter VII of the UN Charter call for the Member States of the United Nations to arrest and bring to trial those accused of piracy before national courts. It is necessary for the States that are involved in anti-Somali piracy efforts to incorporate the principle of universal jurisdiction into their national laws and adopt new laws criminalizing modern piracy, which is outside the traditional notion of piracy stipulated in the United Nations Convention on the Law of the Sea 1982.

\section{KEY WORDS}

$\sim$ Maritime piracy

$\sim$ Armed robbery

$\sim$ Ransom

\section{INTRODUCTION}

The freedom of international maritime has always been one of the most important concerns of the international community because waterways and high seas are the routes through which most global trade passes. The primary hazard faced by ships is unrelated to the sea itself, but is related to the maritime piracy committed by groups with the only aim of stealing cargo or even ships themselves. Nowadays, the international community has shown rare solidarity against this crime by prosecuting perpetrators, destroying their ships and places of gathering, and describing pirates as enemies of humanity. Because this crime threatens international peace and security, the International Law of the Sea was established as a legal framework in the United Nations Convention on the Law of the Sea of 1982.

Traditionally, maritime piracy was practised in specific regions of the world, especially in the Caribbean and the Gulf of Malacca in East Asia, but in the past decade this piracy has emerged strongly in West and East Africa, specifically the Gulfs of Guinea and Aden. Directly or indirectly, it has caused global economic losses. From the Gulf of Aden alone these have reached tens of billions of US dollars. For example, half of the global supply of crude oil passes through this area, in addition to ships carrying various cargoes. ${ }^{1}$

In Somalia, marine piracy and armed robbery have been concentrated in the Somali Territorial Sea, and it affects most

1. According to reports issued by the United Nations Office on Drugs and Crime, losses resulting from piracy in the Gulf of Aden reached more than 18 billion USD in 2006-2013. Moreover, the total sums paid as ransom for the kidnapped vessels was over 413 million USD (2005-2013), at a rate of USD four million per vessel. See:Drobenko, La piraterie saisie par le droit, 21 Neptunes revue (2015) 3; available at: https://cdmo.univ-nantes.fr/neptunus-e-revue/annees-2015/ 
of the commercial ships passing through the Gulf of Aden. The problem here is that the Somali Interim Government announced that it was unable to exercise criminal jurisdiction to pursue and prosecute the perpetrators of these crimes despite this jurisdiction being in accord with both its constitution and international law. The status of Somalia as a failed State has prompted the UN Security Council to ask Members of the UN and even regional organisations such as European Union and African Union to pursue pirates in both the Somali Territorial Sea and on the mainland, and to place them before their national court or before the courts of another country. ${ }^{2}$

The importance of the current Somali case is that, despite international efforts to suppress and eradicate piracy, it has been suppressed, but not eliminated, as the Somali Government announced. Since March 2017 until the time of writing, no ship hijacking or ransom demands have been reported. However, they may recur at any moment once the current coercive measures are relaxed and international military forces are withdrawn. For this reason, it is important to ask whether the existence of a failed State leads to the spread of crimes such as maritime piracy, and whether the presence of piracy and armed robbery in this failed State justifies the intervention of other States seeking to suppress these crimes and prosecute their perpetrators.

\section{CAUSES OF PIRACY IN SOMALIA: A RECENT PHENOMENON}

According to the international law, States exercise jurisdiction within their national borders. Accordingly, criminal jurisdiction is exercised by national authorities. The most prominent of these is their personal jurisdiction over all their lands, territorial seas, and airspace, no matter how high. Any act that constitutes a criminal offence under the State's national law obliges them to pursue and prosecute perpetrators before national courts, and they alone have the right to establish and implement rulings on their territories. ${ }^{3}$ Alongside the countries such as the Democratic Republic of the Congo and Haiti, Somalia is called a failed State. Such a State cannot provide the right to protection and security for its citizens, execute penal law throughout its borders or confront the perpetrators of crimes. In Somalia, this failure is due to the collapse of the political regime

2. Twenty-one countries responded to this call, often through the deployment of warships, including African countries (Kenya, the Seychelles, Tanzania and Mauritius), Arabian countries (Oman, the United Arab Emirates, Yemen and Saudi Arabia), Asian countries (China, South Korea, India, Taiwan and Japan), European countries (the Netherlands, Belgium, France, Germany, the United Kingdom, Russia and Italy), and the United States. Mainiatas, La Piraterie en Afrique, 23 Neptunes revue (2017) 2 ; available at: https://cdmo.univ-nantes.fr/neptunus-e-revue/ annees-2017/

3. Silva, Somalia: State Failure, Piracy, and the Challenge to International Law, 50 Virginia Journal of International Law (2010), 554. in 1991, after the escape of the former President Mohamed Siad Barre, ${ }^{4}$ and the disintegration of the national army, police, and security forces. This dramatic event prompted individuals to establish armed militias not subject to the law, and control over cities and rural areas was ceded to civil warlords. ${ }^{5}$ The Somali State thus fragmented virtually, if not legally, into two parts: Somaliland, and Puntland in Northern Somalia. ${ }^{6}$ Local authorities and institutions were set up in both regions to manage the affairs of cities and regions, and to control security, but the south suffers from armed conflicts that started in 1992 and are ongoing. Armed militias were established which have weakened the State's authority and powers under the Constitution. In addition, there has been a clear and public spread of terrorist groups. ${ }^{7}$

Since its independence from Britain in 1960, and until the 1980s, there were no known piracy incidents in the Somali Territorial Sea. ${ }^{8}$ The first incident was in 1989, at the beginning of the collapse of the political regime and the rupturing of the State. In that year, an armed opposition movement called the Somali National Front became active in the north, in what is known today as Puntland. Backed by Ethiopia, the group held four commercial ships legally sailing across the Somali Territorial Sea and an Italian tanker called Kwanda. The kidnappers claimed to have two motives: to reveal to the world the weakness of the Somali government through its inability to secure protection for foreign ships and to show that the Somali National Front was the most appropriate protection for shipping. Consequently, permission to enter the Somali Territorial Sea should be sought from the opposition movement and not the government. Scholars of international law consider that the Somali National Front borrowed this illegal practice from activities carried out by the Polisario (the Front in the Western Sahara), when it forced fishing

4. President Mohamed Siad Barre took control of Somalia in 1969 and ruled by fomenting disunity among the various clans, and by promoting the Darod clan. He was deposed from power by the General Mohammad Farah Aideed

5. Martin, La Répression des Actes de Piraterie Maritime: Développements Récents en Matière de Poursuites et Détention des Pirates Somaliens' LVI Annuaire Français de Doit International (2010) 517; available at : $h$ ttps://persee.fr/docAsPDF/afdi_00663085_2010_num_56_1_4623.pdf

6. Garrod, The Emergence of Universal jurisdiction in Response to Somali Piracy: An Empirically Informed Critique of International Law's Paradigmatic Universal Jurisdiction, 18 Chines Journal of International Law (2019) 576; available at : https://academic.oup.com/chinesejil/article-abstract/18/3/551/5625568?redirect edFrom=fulltext

7. Farah, Maritime Trade and Piracy in the Gulf of Aden and the Indian Ocean (19942017), April Journal of Transportation Security (2018) 2; available at: https://www. springer.com/journal/12198

8. The author limits of the, maritime zones according to UNCLOS1982 as following: -The territorial sea extends to a limit of 12 nautical miles from the baseline of a coastal State. -The contiguous zone from the outer edge of the territorial sea to a maximum 24 nautical miles from the baseline. -The exclusive economic zone (EEZ) is the largest sea area, which cannot exceed 200 nautical miles from the base line.The high seas are characterized by the principles of free use for all States. For more read the UNCLOS 1982. 
vessels to seek permission from itself and not the Moroccan authorities. Unfortunately, what happened in Somalia after the forced departure of Siad Barre and other regime members, and less than a year after the 1989 Somali incident, was the contrary to what the Front itself declared when it hijacked the ships. Neither the Front nor other opposition movements that emerged later made any effort to control the Somali Territorial Sea. Thus, an area of $120,000 \mathrm{~km}^{2}$ lacked control and authority. ${ }^{9}$

This lack of control on land and at sea created lawlessness in Somalia, and led to the outbreak of piracy discussed here. Perhaps the most prominent of the acts of piracy concern illegal fishing by ships belonging to European, Asian, and African countries without any government control or licencing. Even today, ships from Japan, France, Spain, Pakistan, Taiwan, South Korea, and Sri Lanka practise illegal fishing in the Somali Territorial Sea despite the Security Council resolutions, the latest of which from December 2019, condemning these actions. ${ }^{10}$ Moreover, since the late 1990s, other crimes under international law have also become widespread, i.e. the burial and disposal of nuclear waste and contaminants in the Somali Territorial Sea, human trafficking, and trading in Yemeni Qat. The latter has found a large market in this region and on the coast in particular. ${ }^{11}$ Regarding maritime piracy and armed robbery, in the period 1990-1998, the International Maritime Bureau did not record any piracy incidents in the Somali Territorial Sea, but after 1998 the office began receiving information about ship hijacking, especially in the territorial sea opposite the Puntland region. ${ }^{12}$

It would seem that, when seeking the reasons for the emergence of piracy in Somalia, the fall of the Somali government and the rule of lawlessness since 1991 stand at the forefront. However, scholars of international law retain this is not the only justification. If we take Nigeria as an example, we can see it has a strong federal government and is a member of the Organization of the Petroleum Exporting Countries. Nevertheless, it suffers from pirate groups having emerged there and spread widely. These peoples including the pirates believed that the misallocation of national wealth, especially oil, among various regions in Nigeria led to widespread poverty, specifically

9. Amirelle, La piraterie maritime en Afrique contemporain, 116 Revue de Politique Africaine (2009) 105 ; available at : https://pdfs.semanticscholar.org/d769/8025ec

10. The Security Council stated in its Resolution (Expressing serious concern over reports of illegal, unreported and unregulated fishing (IUU) in Somalia's Exclusive Economic Zone (EEZ), recognizing that IUU fishing can contribute to destabilization among coastal communities, and noting the complex relationship between IUU fishing and piracy,) . See: S/RES/2500/2019, adopted in 4 December ,2019, p. 3 ; available at: www.un.org

11. Edem, Lutte contre la piraterie maritime par des gardes armes à bord des navires: Conflit de compétences entre Etats de pavillon et Etats côtiers-La nécessite de mécanismes de coopération' 21 Neptunes revue 2015) 2 ; available at: https:// cdmo.univ-nantes.fr/neptunus-e-revue/annees-2015/

12. Drobenko, La piraterie saisie par le droit, 21 Neptunes revue (2015) 3; available at: https://cdmo.univ-nantes.fr/neptunus-e-revue/annees-2015/ in the south. When ships loaded with goods and products pass the Nigerian coasts and the poor see them, this prompts them to seize the ships or at least hijack them for ransom..$^{13}$ The same is true for Somalia. Millions of Somalis suffer from poverty and lack of work opportunities, and this has led some to resort to violating the law by committing crimes for money, such as seizing ships inside the Somali Territorial Sea in order to gain the ransom. ${ }^{14}$ However, alongside the factors of the fall of the Siad Barre regime and poverty, the importance of other factors must not be diminished. One is the widespread access to weapons within the civilian population of Somalia, caused by the disintegration of the army, police, and security forces. Another is that, since the British and Italian colonisation of the country ended, many tribal conflicts erupted which pushed people to arm themselves. For this reason, the Somali society is considered to be one of the most armed in all Africa. ${ }^{15} \mathrm{~A}$ third factor is the series of wars that broke out with its neighbour Ethiopia. ${ }^{16}$ Finally, we must mention the lack of technical systems on merchant ships to protect against intruders, or even armed security personnel, meaning that the ships are easier to board. ${ }^{17}$ The Somali pirates are classified as the best equipped and best organised compared to pirate groups in other regions like Malaga Bay, Guinea Bay, or the Caribbean islands. The pirates in Somalia carry automatic weapons and shoulder-held missiles, and use speedboats to move towards their targets. ${ }^{18}$ Considering all of these factors, piracy and armed robbery has become an almost inevitable result in the Somali case.

\section{SECURITY COUNCIL RESOLUTIONS: AUTHORISING INTERNATIONAL INTERVENTION IN SOMALIA}

The International Law of the Sea laid out in the 1982 Convention allows the States to intervene to combat maritime piracy on the high seas or in an exclusive economic zone. Under Article 105 of the United Nations Convention on the Law of the Sea 1982, the States can exercise or not this repression without entailing any international responsibility, especially

13. Flagel, A., Le renouveau de la piraterie internationale, these present a l'universite de la Nouvelle-Caledonie, le 28 fevrier 2013, 343p, 170

14. Piette, The Fight against Maritime Piracy under French Law, 3 Montesquieu Law Review (2015) 2. And for more detailes see: Farah, Supra note 8, at 8.

15. Flagel, $A$., Le renouveau de la piraterie internationale, thèse présenté a l'université de la Nouvelle-Calédonie, le 28 février 2013, p.166. : Hoesslin, Von, La nébuleuse pirate en Somalie, (2012) 56 Diplomatie 42 ; available at: https://www.diplomatie. gouv.fr/fr/conseils-aux-voyageurs/informations-pratiques/risques/pirateriemaritime/

16. Amirelle, Supra note 9, at 105.

17. See article 9 of the Revise Code of Conduct concerning the Repression of Piracy, Armed Robbery, against Ships, and illicit maritime activity in the Western Indian Ocean and the Gulf of Aden Area, in 17 January 2017, p. 70.

18. Treves, Piracy, Law of the Sea, and Use of Force: Developments off the Coast of Somalia, 20 European Journal of International Law (2009) 400. 
since the Convention does not criminalise piracy or include measures for international criminal cooperation and legal assistance to extradite persons accused or convicted of piracy. ${ }^{19}$ In the Somali Case, unlawful acts are committed in the Somali Territorial Sea, and the interference of countries is considered a violation of the sovereignty of a Member State of the UN, even if it is actually described as a failed State. However, sovereignty is a well-established concept in Customary International Law and, therefore, is still enjoyed even by failed States. What is committed in the Somali Territorial Sea differs from what the 1982 Convention refers to, as in the Convention piracy is implied in its traditional sense..$^{20}$

In the Somali Case, foreign ships and crews are detained, and the owning company or flag State of the ship is given a ransom demand for money in exchange for their release. The aim of the detention is, therefore, not the pillaging of the cargo or ship's resources. As a result, we are facing a new form of maritime piracy that differs greatly from what prevailed for centuries. In our opinion, this new form is not described as maritime terrorism ${ }^{21}$ despite the fact that the Security Council Resolution No. 1838 of 2008 describes it as such. ${ }^{22}$ In view of the seriousness of these acts committed in Somalia and their serious impact on the security of maritime navigation and international trade routes, the intervention of the Security Council was necessary to limit attacks against commercial vessels.

Consequently, between May 2008 and December 2019, the Council issued more than thirty binding resolutions based

19. Garrod, supra note 6 at 574 .

20. For the Anglo-Saxon Scholars, the Classical Piracy defined as Attack against all nations indiscriminately and affect the interest of maritime trade throughout the world and by this crime we are all inquired, and individuals in turn can find their personal rights violated. Read: Bantekas, I, Supra note 2, at 156.

21. Maritime terrorism is define as (any act of unlawful violence directed against ships, individuals, goods, or property that they carry, or against maritime targets with the aim of direct or indirect influence on the government of a particular country or any other body to achieve political goals). This crime shares with piracy that they threaten the security of the International Community as a whole, and they constitute international Crimes that threaten the safety of Marine Ships and freedom of Navigation. In addition, both require the use of violence against ships, people and the money they carry. While Piracy differs from Maritime Terrorism in that the Second is not required to be committed on high seas, it can be committed in the Territorial Sea of the State, unlike Piracy in its classical sense, which stipulates its commission on high Seas and the Exclusive Economic Zone. The development of means of using Maritime Terrorism is the opposite of Piracy, which is still using traditional methods. In addition, Piracy is accomplish by fulfilling two conditions, the means used and the target, which is the attacking ship and the assaulted ship. While in maritime terrorism, it may be committee from inside the assaulted ship, that is, by its crew or passengers. The goal of maritime terrorism is vital and strategic, unlike Piracy, whose aim is to plunder or hijack the ship to obtain the funds it carries. Finally, Maritime terrorism aims to cause the largest possible number of losses to the attacked ship, while piracy aims to reduce losses and achieve more profit. See: Eudeline' Le Terrorisme Maritime, Une Nouvelle Forme de Guerre, 2 Outre -Terre Revue (2010) 87 s; available at : https://www.cairn.info/ revue-outre-terre1-2010-2-page-83.htm

22. Farah, Hamza, Supra note 8, at 12. See also: Guilfoyle, Supra note 2, at 146. on Chapter VII of the UN Charter, describing the situation in the Somali Territorial Sea as a threat to international peace and security. This means that the Council can delegate a State to take action to suppress these crimes, including the use of armed force. ${ }^{23}$ Some scholars perceive that the Council intervened in this way, and issued more resolutions related to similar global issues, due to the steady rise of piracy and the serious threat to the freedom of navigation and shipping, both of which negatively affect giant international financial institutions and the global economy. ${ }^{24}$

These Resolutions, since May 2008, consider that any foreign military intervention to suppress piracy and armed robbery requires the explicit and written consent of the SIG in order to carry out these measures. The Somali Interim Government sent a list of countries that will pursue and prosecute pirates in its regional sea to the Secretary-General of the UN. ${ }^{25}$ Moreover, Council Resolutions allow regional organisations to intervene to crack down on illegal acts. In this light, NATO and the EU launched two operations, Ocean Shield and Atlanta, to repress piracy in the Gulf of Aden, and both operations are ongoing in the Somali Territorial Sea twelve years after their launch. ${ }^{26}$ With regard to the list prepared by the Somali Interim Government, the Council Resolutions on the Somali Case were based on Chapter VII of the UN Charter. This means that the commitment to cooperate with the Council to carry out repressive measures is obligatory for all Member States of the UN, and not to the specific group included in the Somali Interim Government list. Because piracy qualifies as a threat to International Peace and Security, the list prepared by the Somali Government for a limited number of Countries was a matter of consideration. For example, when the Council established the International Criminal Tribunal for Rwanda in 1995, it obligated all States to cooperate fully, and any breaches were considered to jeopardise international peace and security. ${ }^{27}$ In the Somali case, if we assume that a country excluded from the Somali Interim Government list discovered a pirate group destined to target a foreign cargo ship in the Somali Territorial Sea, would it stand by and allow the pirates to commit the crime? Would such a problem be a violation of the Council's Resolution on Somalia? On the other hand, the United Nations Convention on the Law of the Sea 1982, especially Articles 100-107 consider that the State's exercise of its full competence to repress piracy

23. The Security Council adopted between May 2008 and December 2019 the following Resolutions: 1814-1816-1838-1844-1846-1851-1897-1918-1950-1976-2015-20202077-2125-2184-2246-2316-2383-2442-2500.

24. Warnir, R., The Prosecution of Pirates in National Courts, 2014, 22.

25. Martin, Supra note 7, at 506

26. Maniatis, Approche Juridique de la Piraterie, 21 Neptunes revue (2016) 5. In the same meaning, read Lorca, Harmonization of National Criminal Laws on Maritime Piracy: A Regulatory Proposal for the Crime of Piracy and its Penalties, 23 European Journal of Criminal Research' (2016) 117.

27. Guilfoyle, Supranote 2, at 152 
is optional, not mandatory. In other words, the country whose warship sees a cargo ship being attacked by a group of pirates has a choice between interfering to prevent piracy or not.

In addition, the UNSC resolutions related to the Somali Case allow the delegated State to intervene by pursuing suspects of piracy, not only in the Somali Territorial Sea, but also on the Somali mainland. ${ }^{28}$ This is a dangerous and negative development with respect to the principle of State sovereignty and territorial integrity. In this paper, we argue that the degree of seriousness of the Council's own Resolutions does not change by limiting maritime and land intervention to Somalia only, or by stipulating that the Somali Case is an exception and, therefore, does not create an International Customary Law. Rather, the emergence of an International Customary Law does not currently arise through a Security Council Resolution or a UN General Assembly Recommendation; instead, it arises from the frequency of an action over an uninterrupted period of time. ${ }^{29}$ Accordingly, we believe that the Council's assertion of the specificity of the Somali case is unacceptable. Every legal issue has international and even internal importance and, therefore, it can be used as a rule or an international legal principle at any time. ${ }^{30}$

\section{PROSECUTION OF SOMALI PIRATES: DELAYED NATIONAL JUSTICE}

It is customary for the Somali Coast Guard forces to do their duty to prosecute the perpetrators of maritime piracy in the Somali Territorial Sea and bring them to trial before the Somali Criminal Courts. The latter, in turn, issue criminal rulings that vary between ruling on innocence, incarceration, imprisonment, or even all the way to execution in some cases, in accordance with the applicable Penal Code and provisions in the Somali penal institutions. However, since this scenario has not been implemented for three decades, the Security Council has intervened and, as indicated above, issued a series of resolutions calling on United Nations' Members States to suppress piracy and armed robbery in the Somali Territorial Sea and to prosecute those suspected of piracy who are Somali citizens. ${ }^{31}$

These resolutions evolved to move from demanding prosecution to requiring states to prosecute pirates before their

28. The number of Council Resolutions that allowed States to intervene on the Somali mainland to pursue suspected pirates reached 7; available at: $h$ ttps://un.org

29. In all UN Resolutions related the Somalia, we found the following text (...Affirms that the authorizations renewed in this resolution apply only with respect to the situation in Somalia and shall not affect the rights, obligations, or responsibilities of Member States under International Law. Including any rights or obligations under The Convention with respect to any other situation, and underscores in particular that this resolution shall not be considered as establishing customary International Law, ).See The Security Council Resolution N. 1897, in 30 November 2009, p.4.

30. Garrod, supra note 6, at 575 .

31. Warnir, Supra note 21, at 21 courts or before the courts of another country, in accordance with either their national laws or the international law in application of universal jurisdiction. Above all, we must consider the position of the Somali legal system with regard to the crime of piracy committed in its territorial waters. This is especially significant given that the United Nations always affirms that its priority is to apply the Somali law against the perpetrators of piracy and armed robbery. In other words, we may question why the Somali Penal Code and other Somali laws, if any, are not applied, and whether there is any justification for the Security Council, with its Resolutions, to call for the application of comprehensive jurisdiction by other countries.

In this regard, we can say first that the Somali criminal law in force (Penal Code, Criminal Procedure Law) is based on four contradictory legal sources: Italian law, Anglo-Saxon law, Islamic law, and Somalia's prevailing tribal customs. ${ }^{32}$ With regard to the Somali Penal Code promulgated in 1962, it was derived, if not quoted, in the majority of its provisions from the Italian Penal Code, while the Code of Criminal Procedures is derived from Anglo-Saxon law. These two laws are still in force in all parts of Somalia, even in the regions that announced their official (Somaliland) or administrative secession (Puntland). ${ }^{33}$

The main criticism of the Somali Penal Code is that it does not refer to the crime of maritime piracy in its texts despite Somalia's being a maritime nation with more than $3.000 \mathrm{~km}$ of coasts, and piracy being a historical and ancient crime. For many, the lack of stipulation in the Penal Code is due to two reasons. First, there was no commitment in the period before the collapse of the State in 1991 and, thus, no call for an amendment to the law from its promulgation until the fall of the political regime. Second, to punish piracy crimes, the Somali judiciary could have employed provisions on kidnapping crimes according to Articles 485-486 of the Penal Code. These two texts relate to the crimes of kidnapping persons in exchange for a financial ransom whether committed on land, sea or air, as the text does not specify the place of commission. The punishment stipulated in the law ranges between eight to eighteen years in prison, depending on any aggravated circumstances or exemptions, which might affect the punishment accordingly. ${ }^{34}$

Other difficulties related to the implementation of the Somali Penal Code relate to the first source of criminalization in the Code, which is Islamic Sharia. According to this Sharia, maritime piracy is the crime of brigandry (hiraba). Under this law,

32. See the Report of the Secretary General on the modalities for the establishment of specialized Somali anti-piracy Courts, S/2011/30, p. 40.

33. See: The Somali Penal Code, N 5, in 16 December 1962, and the Somali Code of Criminal Procedures N. 1, in June 1963.

34. Shnider, Universal Jurisdiction over Operation of a Pirate Ship: The Legality of the Evolving Piracy Definition in Regional Prosecutions, 38 North California Journal of International Law and Commercial Regulation (2013) 522 ; available at : https:// www https://scholarship.law.unc.edu/ncilj/vol38/iss2/3/ 
a cruel punishment equivalent to torture was imposed: cutting off the left leg and the right hand and, in case of recidivism, the right leg and the left hand. These penalties contradict the modern criminal policy of reforming and rehabilitating convicts wherever their crimes are and, therefore, it is not realistic for use in the Somali Penal Code.

To overcome these difficulties, the United Nations Office on Drugs and Crime (UNODC) has provided substantial and generous support to local governments in the Puntland and Somaliland regions to establish effective judicial institutions and train judicial, legal, and technical personnel. Its support included both material assistance and participation in the legislation of laws punishing piracy in these regions. Here, we note the success of the programme's efforts in Somaliland, where in 2012 a local law was legislated to combat maritime piracy. ${ }^{35}$

With regard to the Somaliland Law to Combat Maritime Piracy, it is classified as a special criminal law. According to Article 12 , it is part of the Penal Code in force and this is the Law of 1962; however, no Penal Code was issued in Somaliland, and the Somali Penal Code of 1962 is still in force alongside the Somali Penal Procedures Law. This means that all criticism of the Somali Law remains the same, with the exception that in adapting the act of piracy and punishment, the new law identified the action committed as maritime piracy and set its punishment as 5-20 years in prison. ${ }^{36}$

Moreover, the new law limits criminal jurisdiction to the Somaliland Courts for all the piracy crimes committed in the Territorial Sea of Somaliland despite the non-demarcation of the maritime boundaries between the Republic of Somalia, a signatory to the 1982 Convention, and Somaliland unless the crime is subject to the jurisdiction of another country or criminal jurisdiction under the Common International Law and the intention is universal jurisdiction. It appears that, with the influence of the UNODC, the legislator of the law aimed to immediately address piracy in the Somaliland waters as much as possible. ${ }^{37}$

Despite the issuance of a somewhat recent law compared to the laws in force in Somalia, it is unfortunate that this law has

35. The Somali Land law combatting the Piracy, N 52, in September 2012, also See: The Report of the Secretary-General on the situation with respect to piracy and armed robbery at sea off the coast of Somalia, S/2013/623, in 21 October 2013, p. 5.

36. The main provision is the Article 5 of the Law against the Piracy which stated that 1) An act of piracy at a ship or aircraft owned by Somaliland shall come under the jurisdiction of the Republic of Somaliland courts unless the ship or aircraft was, at the time of the commission of the offence, situated in the territorial waters of another country or that act is assigned, under international law, to another jurisdiction; 2) Notwithstanding the provisions of any other law and regardless of the nationality of the accused persons, the courts of Somaliland shall have jurisdiction to try any offences of piracy committed within the Somaliland sea or outside the Somaliland sea if committed in an area not falling within the sea of any other country when the Somaliland Coastal Forces detains the accused persons).

37. Lorca, Supra note 23, at 118. not to date been widely applied, mainly because of the weakness of the judicial institutions in Somaliland. This is in addition to the fact that influential bodies benefit from the practice of maritime piracy and, thus, do not allow the prosecution of pirates before local courts. To demonstrate this apparent weakness, in August 2019, the Somaliland authorities released 19 convicted pirates who had been moved from the Seychelles to Somaliland, based on a Memorandum of Understanding, to spend their sentences in Somaliland. ${ }^{38}$ However, the latter released them. This was qualified as a violation of Somaliland's obligation to the Seychelles and the international community to imprison the convicted persons within two prisons constructed with funds from the United Nations, which also trained their cadres in previous years. In the light of the above-mentioned difficulties in applying the Somali law before the Somali courts, it became imperative for the Security Council to find a legal solution that achieves justice.

\section{CONCLUSION}

Currently, the UN Security Council still plays a decisive role in the international campaign against the Somali piracy. This achievement is considered result from unanimity of the five permanent members of the Security Council and their satisfaction with the gravity of this crime and its impact on their commercial interests and national security. The Security Council has adopted more than forty resolutions in the past twelve years, including those that promote procedures related to the reestablishment of judicial institutions (i.e. the courts) in Somalia. These institutions were wholly damaged in the war, along with the legislative reform of the criminal laws in Somalia enacted six decades ago.*

Unfortunately, however, the Council has failed in its efforts on behalf of the Somalian judicial institutions. On the positive side, the Council called all the member States of the UN to integrate the principle of universal jurisdiction into their national criminal laws in order to prosecute piracy before national courts, due to the incapability of carrying out the United Nations Convention on the Law of the Sea 1982 upon the Somali situation. However, the application of universal jurisdiction by these countries faces a problem related to the difference in the sanctions imposed by the Courts: in the northern countries five years in prison is the maximum, while in the southern countries piracy incurs death penalty.

38. It should be mentioned that the Security Council recognized in its resolutions the weakness of the Somali criminal laws, even the inability of the Somali Courts for pursuit and prosecution of the pirates. For more details read the following Resolutions: S/RES/1918(2010)-S/RES/1897(2009)-S/RES/1950(2010)-S/ RES/1976(2011)-S/RES/2125(2013), S/RES/2246(2015)-S/RES/2500(2019).

* The resolutions mentioned to re-establish the judicial institutions in Somali are: $N$. 2500-N $2383-N 2246-N 2184-N 2125$ - N 2077 - N 2015 - N 1976 


\section{REFERENCES}

Amirell, S.E. \& Ndzesop, I., 2009. La piraterie maritime en Afrique contemporaine. Politique africaine, 116(4), p.97. Available at:

http://dx.doi.org/10.3917/polaf.116.0097.

Bantekas, I., 2003. International Criminal Law. Available at: http://dx.doi.org/10.4324/9781843145295.

Drobenko, B., 2015. La piraterie saisie par le droit, Neptunes revue, 21, pp. 1-9.

Edem, S., 2015. Lutte contre la piraterie maritime par des gardes armes à bord des navires : Conflit de compétences entre Etats de pavillon et Etats côtiers - La nécessite de mécanismes de coopération. Neptunes revue, 3, pp. 1-10.

Eudeline, H., 2010. Le terrorisme maritime, une nouvelle forme de guerre. OutreTerre, $n^{\circ} 25-26(2)$, p.83. Available at: http://dx.doi.org/10.3917/oute.025.0083.

Farrah, H., 2018. Maritime Trade and Piracy in the Gulf of Aden and the Indian Ocean (1994-2017). Journal of Transportation Security, pp. 1-19.

Garrod, M., 2019. The Emergence of "Universal Jurisdiction" in Response to Somali Piracy: An Empirically Informed Critique of International Law's "Paradigmatic" Universal Jurisdiction Crime. Chinese Journal of International Law, 18(3), pp.551643. Available at: http://dx.doi.org/10.1093/chinesejil/jmz025.

Gaurier, D., 2000. Le crime contre l'humanité est-il une notion nouvelle ? Le pirate, ennemi du genre humain. Annuaire de Droit Maritime et Océanique, XVIII, pp.173192.

Guilfoyle, D., 2016. Counter- Piracy Law Enforcement and Human Rights. International and Comparative Law Quarterly 59, pp.141-169.

López Lorca, B., 2016. Harmonisation of National Criminal Laws on Maritime Piracy: a Regulatory Proposal for the Crime of Piracy and its Penalties. European Journal on Criminal Policy and Research, 23(2), pp.115-132. Available at: http://dx.doi.org/10.1007/s10610-016-9325-y.

Maniatis, A., 2016. Approche Juridique de la Piraterie, Neptunes revue, 22(1).

Maniatis, A., 2017. La Piraterie en Afrique, Neptunes revue, 23, pp.1-6.

Martin, J.-C., 2010. La répression des actes de piraterie maritime : développements de poursuites et détention des pirates somaliens. Annuaire français de droit international, 56(1), pp.497-527. Available at: http://dx.doi.org/10.3406/afdi.2010.4623.

Piette, G., 2015. The Fight against Maritime Piracy under French Law. Montesquieu Law Review, 3, pp. 2-10.

Shnider, S., 2013. Universal Jurisdiction over Operation of a Pirate Ship: The Legality of the Evolving Piracy Definition in Regional Prosecutions. North California Journal of International Law and Commercial Regulation, 38(2), pp. 474-569.

Silva, M., 2010. Somalia: State Failure, Piracy, and the Challenge to International Law. Virginia Journal of International Law, 50, pp. 553-578.

Treves, T., 2009. Piracy, Law of the Sea, and Use of Force: Developments off the Coast of Somalia. European Journal of International Law, 20(2), pp.399-414. Available at: http://dx.doi.org/10.1093/ejil/chp027.

Warnir, R., 2014. The Prosecution of Pirates in National Courts. Abu Dhabi. ECSSR.

\section{Somalian laws}

Law on Combatting Piracy (Somaliland). N .52, in 2012.

Penal Code (Somalia Republic) N. 5, in 16 December 1962.

Procedures Criminal Code (Somalia Republic) N1, in 13 June 1963.

\section{Conventions}

United Nations Convention on the Law of the Sea 1982.

Convention for the Suppression of Unlawful acts against the safety of maritime navigation 1988.

\section{United Nations Reports}

The Report of the Secretary-General on the modalities for the establishment of specialized Somali anti-piracy courts. S/2011/360, on 15 June 2011.

The Report of the Secretary-General on the situation with respect to piracy and armed robbery at sea off the coast of Somalia, S/2013/623, on 21 October 2013.

The Revise Code of Conduct concerning the Repression of Piracy, Armed Robbery, against Ships, and illicit maritime activity in the Western Indian Ocean and the Gulf of Aden Area, on 17 January 2017

\section{Security Council Resolutions}

S/RES/1816, on 26 May 2008.

S/RES/1831, on 19 August 2008.

S/RES/1838, on 7 October 2008

S/RES/1844, on 20 November 2008.

S/RES/1846, on 2 December 2008

S/RES/1851, on 16 December 2008.

S/RES/1872, on 26 May 2009.

S/RES/1897, on 30 November 2009.

S/RES/1916, on 19 March 2010.

S/RES/1918, on 23 April 2010.

S/RES/1950, on 23 November2010.

S/RES/1976, on 11 April 2011.

S/RES/2010, on 30 September 2011.

S/RES/2015, on 24 October 2011.

S/RES/2142, on 5 March 2014

S/RES/2158, on 29 May 2014.

S/RES/2221, on 26 May 2015.

S/RES/2232, on 28 July 2015.

S/RES/2275, on 24 March 2016.

S/RES/2289, on 27 May 2016.

S/RES/2297, on 7 July 2016.

S/RES/2444, on 14 November 2018.

S/RES/2500, on 4 December 2019. 